\title{
Correction: Impact of genotype 1 and 2 of porcine reproductive and respiratory syndrome viruses on interferon-a responses by plasmacytoid dendritic cells
}

\author{
Arnaud Baumann ${ }^{1,2}$, Enric Mateu ${ }^{3}$, Michael P Murtaugh $^{4}$ and Artur Summerfield ${ }^{1 *}$
}

\section{Correction}

After the publication of our article [1], we noted that the porcine reproductive and respiratory syndrome virus (PRRSV) strain referred to as SY0608 was not referred to correctly.

The correct reference for this PRRSV strain is RVB$581[2,3]$, not SY0608.

We apologise for this oversight and any inconvenience this may have caused.

\footnotetext{
Author details

'Institute of Virology and Immunoprophylaxis (IVI), Sensemattstrasse 293,

3147 Mittelhäusern, Switzerland. ${ }^{2}$ Graduate School for Cellular and

Biomedical Sciences, University of Bern, Bern, Switzerland. ${ }^{3}$ Centre de Recerca en Sanitat Animal (CReSA), UAB-IRTA, Campus de la Universitat Autònoma de Barcelona, 08193, Bellaterra, Barcelona, Spain. ${ }^{4}$ Department of Veterinary and Biomedical Sciences, University of Minnesota, St. Paul, MN 55108, USA.
}

Received: 21 August 2013 Accepted: 21 August 2013

Published: 11 September 2013

\section{References}

1. Baumann A, Mateu E, Murtaugh MP, Summerfield A: Impact of genotype 1 and 2 of porcine reproductive and respiratory syndrome viruses on interferon-a responses by plasmacytoid dendritic cells. Vet Res 2013, 44:33.

2. Wernike K, Bonilauri P, Dauber M, Errington J, LeBlanc N, Revilla-Fernández S. Hjulsager C, Isaksson M, Stadejek T, Beer M, Hoffmann B: Porcine reproductive and respiratory syndrome virus: interlaboratory ring trial to

* Correspondence: artur.summerfield@ivi.admin.ch

'Institute of Virology and Immunoprophylaxis (IVI), Sensemattstrasse 293,

3147 Mittelhäusern, Switzerland evaluate real-time reverse transcription polymerase chain reaction detection methods. J Vet Diagn Invest 2012, 24(5):855-866.

3. Wernike K, Hoffmann B, Dauber M, Lange E, Schirrmeier H, Beer M: Detection and typing of highly pathogenic porcine reproductive and respiratory syndrome virus by multiplex real-time rt-PCR. PLoS One 2012, 7(6):e38251.

\section{doi:10.1186/1297-9716-44-74}

Cite this article as: Baumann et al.: Correction: Impact of genotype 1 and 2 of porcine reproductive and respiratory syndrome viruses on interferon-a responses by plasmacytoid dendritic cells. Veterinary Research 2013 44:74.

\section{Submit your next manuscript to BioMed Central and take full advantage of:}

- Convenient online submission

- Thorough peer review

- No space constraints or color figure charges

- Immediate publication on acceptance

- Inclusion in PubMed, CAS, Scopus and Google Scholar

- Research which is freely available for redistribution 